\title{
Protective Actions of L-Aspartate from Acid or Proteolytic Inactivation
}

\author{
Nobuo NaKamura \\ Tokyo Research Laboratory, Kyowa Hakko Kogyo Co., Ltd., \\ Asahi-machi, Machida, Tokyo \\ Received September 1, 1972
}

(1) L-Aspartate was found to replace L-asparagine in the protective action from acid inactivation of L-asparaginase (EC 3.5.1.1) produced by Escherichia coli A-1-3 and at the same time to inhibit the proteolytic inactivation by $\alpha$-chymotrypsin.

(2) L-Asparaginase changed in its chromatographic properties in the presence of L-aspartate and became to be absorbed on the CM Sephadex column.

(3) The sedimentation patterns of L-asparaginase at pH 3.5 were identical either in the presence or absence of L-aspartate, showing partial dissociation. But the reversibility to the active state was observed only in the enzyme dissolved in the solution containing Laspartate.

(4) L-Aspartate did not prevent the enzyme either from the dissociation into subunits or from decrease in the activity by urea.

(5) High concentration of L-aspartate was shown to inhibit the L-asparagine hydrolysis reaction.

(6) L-Aspartate was suggested from ORD measurements to cause changes in the higher structure as well as the ionic properties or proteolytic inactivation.

Since the antineoplastic principle in guinea pig serum was identified with L-asparaginase, ${ }^{1 \text {, }}$ the enzymes from various origins were examined for the antitumor activities and many studies have been reported on the enzymological properties of the enzymes.

L-Asparaginase from Escherichia coli A-1-3, a mutant of $E$. coli HAP, was similar to EC 2 from $E$. col $i$ B in the anti-leukemia activity, ${ }^{2,31}$ the physico-chemical properties ${ }^{4,5)}$ and the substrate specificities. ${ }^{6,7)}$ Some differences, however, were noticed between them, for example, the enzyme from $E$. coli A-1-3 did not contain cystine or cysteine residues.

Cooney and Davis ${ }^{8)}$ demonstrated that Lasparagine accelerated the thermal denaturation of the enzyme from $E$. coli $\mathrm{B}$, while we observed with the enzyme from $E$. coli $\mathrm{A}-1-3$ that L-asparagine did not accerelate the thermal inactivation, but showed a weak protection against it. Furthermore, L-asparagine remarkably protected the enzyme from

L-Asparaginase from Escherichia coli. Part III. inactivation by acid or proteases. This protective action of L-asparagine could be reproduced by L-aspartate more effectively. In addition, L-aspartate changed the chromatographic behaviors of the enzyme, but did not interfere with the dissociation of the enzyme into subunits.

The present investigation was undertaken to characterize the effect of L-aspartate on the stability of the enzyme.

\section{MATERIALS AND METHODS}

L-Asparaginase was prepared from Escherichia coli A-1-3 as previously reported. ${ }^{5}$, The enzyme activity was determined by measuring the amount of ammonia formed with nesslerization in the standard assay system, ${ }^{5)}$ unless otherwise specified.

Ultracentrifugal studies were carried out with a Hitachi U.C.A. 1A ultracentrifuge equipped with Schlieren optics. Sedimentation velocity was measured usually with the final speed of $60,000 \mathrm{rpm}$ at $20^{\circ} \mathrm{C}$. Under acidic conditions, it was measured at $51,200 \mathrm{rpm}$ using a Kel-F cell. When multiple peaks appeared, the relative concentration of each component was 
approximated by integrating the areas under each schlieren peak.

Optical rotatory dispersion measurements were performed with a Jasco ORD/UV-5. In every measurement, optical rotatory dispersion coefficient $\lambda_{t}$ was calculated from the slope of Yang's plot, in which $[\alpha]_{\text {, }}$ was compensated for the effect of the solvent, and the helix content was deduced from $\lambda_{c}$, using Yang's empirical equation. ${ }^{9}$

\section{RESULTS \\ Protective effects of some amino acids on acidic inactivation of L-asparaginase}

Since L-asparagine, the substrate, protects L-asparaginase from $E$. coli $\mathrm{A}-1-3$ against acid inactivation, s' some compounds related to $\mathrm{L}$-asparagine were examined for their protective effect. As shown in Table I, only $26.4 \%$ of the original activity remained after the acidic incubation of the enzyme in the absence of amino acids. The enzyme solutions containing L-aspartate or L-asparagine retained about $90 \%$ of the original activity, and D-aspartate showed a weak protective effect. Other amino acids did not exhibit comparable positive effect.

Considering that the asparaginase is considerably active at $\mathrm{pH} 3.5$ and D-aspartate showed a weak but more effective protection than $\mathrm{D}$-asparagine did, the protective effect of $\mathrm{L}$-asparagine might be ascribed to L-aspartate formed from L-asparagine during the acidic incubation.

The effects of L-aspartate and L-asparagine on acidic inactivation were compared at $\mathrm{pH} 2.8$, at which the enzymatic hydrolysis of L-asparagine was expected to be negligible. The result (Table II) suggests that the protection against acidic inactivation was effected by $\mathrm{L}$-aspartate but not by L-asparagine, the substrate of the enzyme.

The effects of L-aspartate on the stability of the enzyme at various $\mathrm{pH}$ are shown in Fig. 1. L-Aspartate showed a very weak protection at alkaline $\mathrm{pH}$.

\section{Effects of L-aspartate on chromatographic} behaviors of L-asparaginase
Table I. Effects of Amino Acids on the STABILITY AT pH 3.5

The incubation mixture consisting of the enzyme, $20 \mathrm{~mm}$ amino acid, and $50 \mathrm{~mm}$ buffer (acetate buffer $\mathrm{pH} 3.5$ or phosphate buffer $\mathrm{pH} 8.0$ ) was incubated at $47^{\circ} \mathrm{C}$ for $60 \mathrm{~min}$ and the remaining activity was assayed.

The remaining activity of the enzyme incubated at $\mathrm{pH} 8.0$, which was nearly equal to the initial activity, was assumed to be $100 \%$.

\begin{tabular}{lcc}
\hline \multicolumn{1}{c}{ Addition } & $\mathrm{pH}$ & $\begin{array}{c}\text { Activity remained } \\
(\%)\end{array}$ \\
\hline none & 8.0 & 100.0 \\
& 3.5 & 26.4 \\
L-Asparagine & 3.5 & 91.2 \\
L-Aspartate & 3.5 & 87.3 \\
D-Asparagine & 3.5 & 29.8 \\
D-Aspartate & 3.5 & 53.5 \\
L-Glutamine & 3.5 & 25.7 \\
L-Glutamate & 3.5 & 26.3 \\
L-Cysteine & 3.5 & 29.3 \\
L-Homoserine & 3.5 & 22.7 \\
\hline
\end{tabular}

Table II. Comparison of Protective Action agAINST ACID INACTIVATION BETWEeN L-ASPARTATE AND L-ASPARAGINE

The incubation mixture was consisted of enzyme (50 units), buffer (100 $\mathrm{mm}$ ) and L-aspartate or Lasparagine $(0,1,5$ and $20 \mathrm{~mm})$. The remaining activity was assayed after the incubation at $47^{\circ} \mathrm{C}$ for $30 \mathrm{~min}$.

\begin{tabular}{cccc}
\hline \multirow{2}{*}{$\mathrm{pH}$} & $\begin{array}{c}\text { Amino acid } \\
\text { concentration } \\
\text { mM }\end{array}$ & \multicolumn{2}{c}{ Activity remained } \\
\cline { 3 - 4 } & 0 & \multicolumn{2}{c}{$100 \%$} \\
L-Aspartate & L-Asparagine \\
\hline 8.0 & 0 & 35.8 & 39.1 \\
2.8 & 1 & 48.0 & 35.1 \\
2.8 & 5 & 89.5 & 41.7 \\
2.8 & 20 & & \\
2.8 & & &
\end{tabular}

L-Aspartate was proved useful to stabilize the enzyme in CM Sephadex column chromatography. When L-asparaginase was applied on a CM Sephadex column equilibrated with

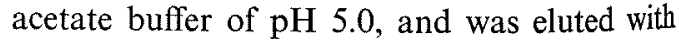
the same buffer using a linear concentration gradient of sodium chloride, the enzyme activity was recovered in a yield of about $50 \%$ (Fig. 2A). On the other hand, when the enzyme was dialyzed against the acetate buffer containing $10 \mathrm{mM}$ L-aspartate, and 


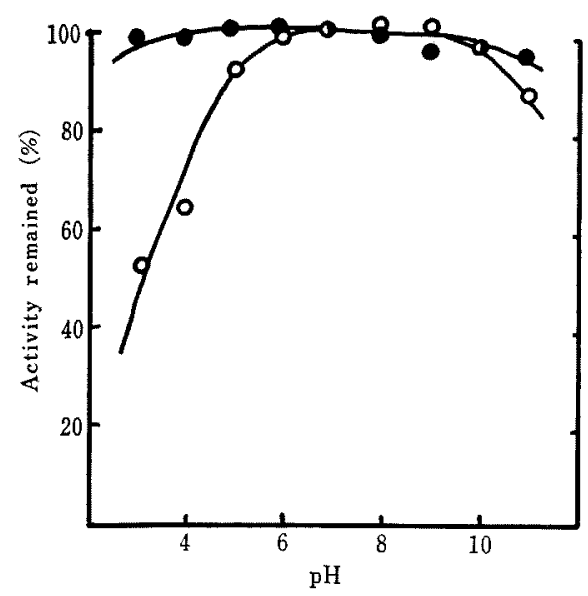

FiG. 1. Effect of $\mathrm{pH}$ on the Stability of L-Asparaginase.

The incubation mixture of (a) $0.2 \mathrm{ml}$ of the enzyme solution $(50 \mathrm{u} / \mathrm{ml}), 0.7 \mathrm{ml}$ of buffer $(0.05 \mathrm{M})$ and $0.1 \mathrm{ml}$ of water $\mathrm{O}-\mathrm{O}$, or (b) $0.1 \mathrm{ml}$ of L-aspartate $(10 \mathrm{~mm})$ in place of water - was incubated at $47^{\circ} \mathrm{C}$ for $60 \mathrm{~min}$. The remaining activity was assayed at $\mathrm{pH}$ 8.0. $\mathrm{pH} 3 \sim 5$ : acetate, $\mathrm{pH}$ 6 8: phosphate, pH 9 11: borate buffer.

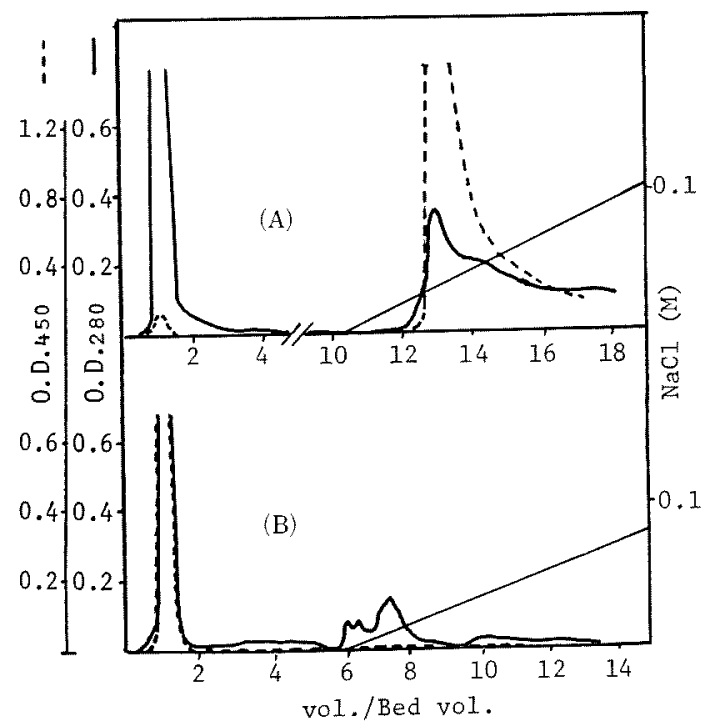

Fig. 2. CM Sephadex Column Chromatographies with and without L-Aspartate.

The columns and sample solutions were bufferized with $0.01 \mathrm{M}$ acetate buffer, $\mathrm{pH} 5.0$, (A) not containing or (B) containing $20 \mathrm{mM} \mathrm{L}$-aspartate and the same buffers were used for the elution with linear gradient of $\mathrm{NaCl}$ concentration. O.D. 450 shows the color intensity of the nesslerization which stands for the enzyme activity of the fractions. applied on a CM Sephadex column equilibrated with the same buffer, the enzyme activity was not absorbed on the column but was washed out with the buffer containing L-aspartate in a yield of $93 \%$ (Fig. 2B).

The differences between the elution profiles and the yields of the enzyme were obviously caused by the addition of L-aspartate to the buffer because these phenomena were observed solely with the asparaginase protein.

L-Glutamate did not show the similar effects.

Inhibition of proteolytic inactivation by ${ }^{2}$ aspartate.

L-Asparaginase from $E$. coli A-1-3 was inactivated by the action of proteolytic enzymes. The incubation of the enzyme with proteases, such as $\alpha$-chymotrypsin, caused the decrease of the activity as shown in Fig. 3 curve A. L-Asparagine has been previously shown to protect the enzyme from proteolytic inactivation. ${ }^{10}$ As shown in Fig. 3 curve B, L-aspartate protected the enzyme similarly against the inactivation by $\alpha$-chymotrypsin. The protective effects of L-aspartate were observed against other proteases as well. Of several proteases examined, $\alpha$-chymotrypsin inactivated the most effectively and trypsin, subtilisin and thermolysin in the succeeding order.

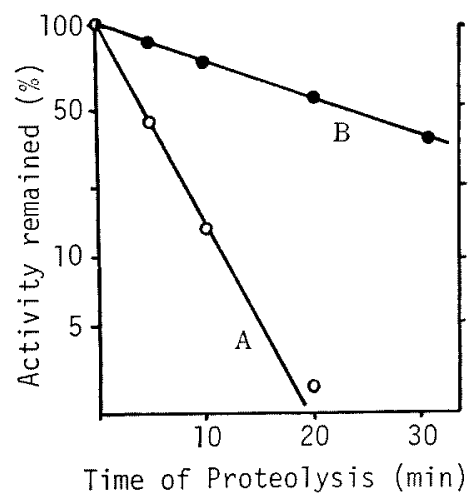

Fig. 3. Effect of L-Aspartate on the Proteolytic Inactivation.

The incubation mixture consisted of $1 \mathrm{ml}$ of enzyme $(1 \mathrm{mg} / \mathrm{ml}), 1 \mathrm{ml}$ of $\alpha$-chymotrypsin $(5 \mathrm{r} / \mathrm{ml})$ and $1 \mathrm{ml}$ of phosphate buffer (A) $\mathrm{O}-\mathrm{O}$, or $1 \mathrm{ml}$ of L-aspartate $30 \mathrm{~mm}$ in phosphate buffer (0.1 M, pH 7.4) (B) $-\bullet$. At each time indicated, $0.1 \mathrm{ml}$ of the mixture was introduced into an assay tube, containing L-asparagine $22 \mathrm{~mm}, \mathrm{pH} 8$. The reaction time for assay was $2 \mathrm{~min}$. 


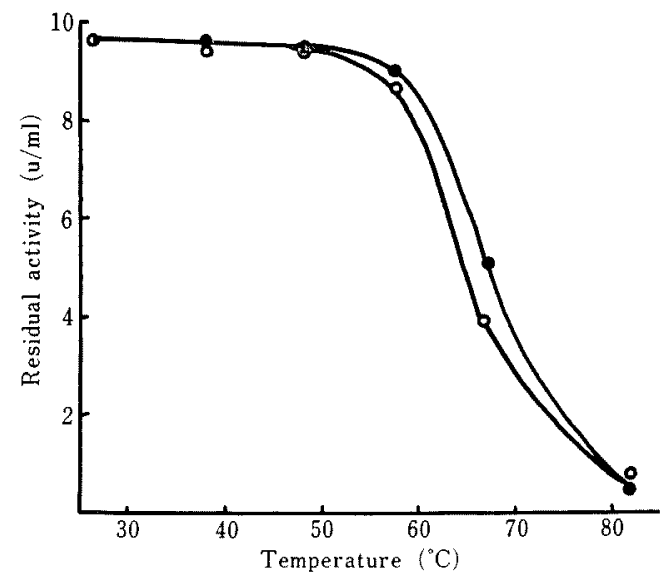

FIG. 4. Effect of Temperature on L-Asparaginase Stability.

The incubation mixtures consisted of (a) enzyme and phosphate buffer pH $8.0 \bigcirc-\mathrm{O}$, or (b) enzyme, phosphate buffer and $\mathrm{L}$-aspartate $10 \mathrm{~mm}-\mathrm{-}$, were incubated at temperature indicated for $30 \mathrm{~min}$ and the remaining activity was assayed.

The disc electrophoretic patterns of the asparaginases treated with $\alpha$-chymotrypsin in the presence and in the absence of $\mathrm{L}$-aspartate did not differ each other, though their enzymatic activities were entirely different.

\section{Effects of $L$-aspartate on thermal treatment}

L-Asparaginase was relatively stable against heat. As shown in Fig. 4, when the enzyme solution of $\mathrm{pH} 8.0$ was incubated for $30 \mathrm{~min}$ at various temperatures, the activity began to decrease at $60^{\circ} \mathrm{C}$ and became to zero at $80^{\circ} \mathrm{C}$. In this heat treatment, L-aspartate did not appreciably broaden the stable region. However, a weak but distinct suppression of heat inactivation was observed in the presence of L-aspartate from $60^{\circ} \mathrm{C}$ to $80^{\circ} \mathrm{C}$, where the remaining activity was decreasing. For example, $52.3 \%$ of the initial value was retained in the presence of L-aspartate, while $40 \%$ remained in its absence at $66^{\circ} \mathrm{C}$.

Effect of L-aspartate on inhibition by protein denaturants

L-Asparaginase was also relatively stable against alcohol and other solvents. In the purification procedure, the enzyme protein was precipitated by adding $n$-propyl alcohol (50\% $\mathrm{v} / \mathrm{v}$ ) at room temperature without loss of activity. Similar results were obtained when other solvents such as ethanol or acetone, were used. However, these solvents inhibited the enzyme activity. In $10 \mathrm{M}$ methanol solution, the enzyme activity was reduced to $43 \%$ of the value measured in the absence of methanol, irrespective of the presence of L-aspartate, as shown in Table III. In both cases, the reduced activities were recovered up to the original levels by removing methanol.

Similar results were obtained with urea (Table III). The enzyme activity was completely recovered when urea was removed by dialysis.

\section{Table III. EFfect of l-Aspartate on the Enzyme Activity in the Presence of METHANOL OR UREA}

The assay mixtures in which methanol (10 mM) or urea $(4$ or $8 \mathrm{M}$ ) were added to the usual assay mixture $(22 \mathrm{mM}$ L-asparagine in $0.1 \mathrm{M}$ phosphate buffer pH 8.0) were used in the assay. Other conditions were the same as in the usual enzyme assay.

\begin{tabular}{cccc}
\hline & $\begin{array}{c}\text { Denaturant } \\
\text { M }\end{array}$ & $\begin{array}{c}\text { L-Aspartate } \\
\text { added } \\
\text { mM }\end{array}$ & $\begin{array}{c}\text { Activity } \\
\text { remained } \\
\%\end{array}$ \\
\hline \multirow{4}{*}{ Methanol } & 0 & 0 & 100.0 \\
& 10 & 0 & 42.8 \\
& 0 & 10 & 103.5 \\
& 10 & 10 & 43.2 \\
\hline \multirow{4}{*}{ Urea } & 0 & 0 & 100.0 \\
& 4 & 0 & 51.5 \\
& 8 & 0 & 2.9 \\
& 0 & 10 & 100.0 \\
& 4 & 10 & 53.8 \\
& 8 & 10 & 0 \\
\hline
\end{tabular}

These results indicated that L-aspartate did not interfere with the inhibition of the enzyme by protein denaturants.

\section{Effect of L-aspartate on subunit structure}

It was already demonstrated in disc electrophoresis and sedimentation studies that Lasparaginase was composed of a few subunits and the treatment of the enzyme with urea or guanidine hydrochloride resulted in its dissociation into the subunits. ${ }^{10}$ 
In order to determine whether L-aspartate interfered with the dissociation and the association of the enzyme, sedimentation measurements were carried out with the enzyme solutions both with and without L-aspartate, in the presence of $3 \mathrm{~m}$ urea. Figure 5 shows the photographs taken at $72 \mathrm{~min}$ after reaching $60,000 \mathrm{rpm}$ at $20^{\circ} \mathrm{C}$.

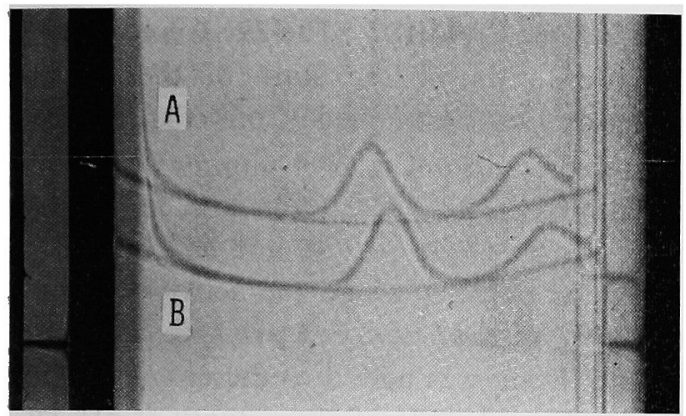

FIG. 5. Sedimentation Patterns of L-Asparaginase in the Presence of $3 \mathrm{~m}$ Urea.

The protein concentration was $1.5 \%$, dissolved in $3 \mathrm{~m}$ urea of $0.05 \mathrm{M}$ phosphate buffer $\mathrm{pH} 8.0$ solution (A) containing $10 \mathrm{~mm}$ L-aspartate of (B) not containing L-aspartate. Picture was taken at 72 min after achieving maximum speed $(60,000 \mathrm{rpm})$.

The sedimentation pattern of the enzyme in the absence of L-aspartate was very similar to the pattern obtained in the presence of Laspartate. In both cases, two peaks were observed; the fast sedimenting peak obtained in the presence of L-aspartate was calculated to be $7.6 \mathrm{~s}$ and that in the absence of $\mathrm{L}$-aspartate $7.5 \mathrm{~s}$ and the slowly sedimenting peaks were calculated to be $2.5 \mathrm{~s}$ in both cases. The $7.5 \mathrm{~s}$ peak appears to represent the native enzyme and the $2.5 \mathrm{~s}$ peak its dissociated components, respectively. The relative concentrations of the two peaks were approximated by integrating the areas under the two schlieren peaks and the $7.6 \mathrm{~s}$ components were estimated to constitute $58.4 \%$ of the total proteins in the presence of L-aspartate and $62.7 \%$ in its absence. The difference between these values appears negligible.

These findings show that L-aspartate did not affect the dissociation of the enzyme into the subunits by urea and its protective action against the inhibition of the enzyme might be related to other mechanisms than the dissociation of the enzyme.

L-Asparaginase activity was lost at a low $\mathrm{pH}$ range and its loss was reduced in the presence of L-aspartate as shown in Fig. 1. On the other hand, L-asparaginase EC 2 from $E$. coli $\mathrm{B}$ was reported to be dissociated into the $3.9 \mathrm{~s}$ components at $\mathrm{pH} 2.2 .^{11}$ Thus, if this is true with L-asparaginase from $E$. coli $\mathrm{A}-1-3$, there might be a possibility that the dissociation of the enzyme at acid condition was inhibited by aspartate, because it suppressed the acid inactivation of the enzyme. The effects of L-aspartate on the sedimentation patterns at $\mathrm{pH} 3.5$ are shown in Fig. 6.

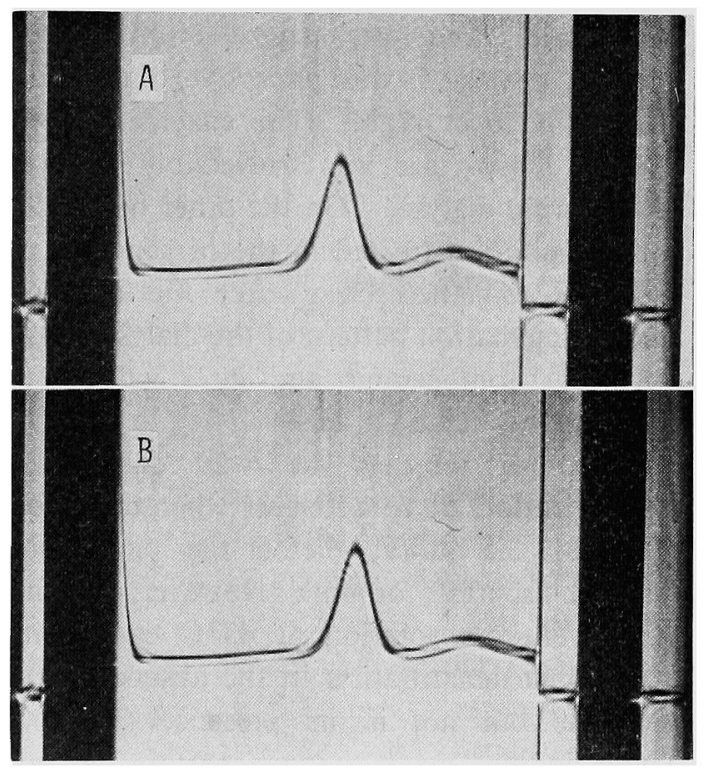

FIG. 6. Sedimentation Patterns of L-Asparaginase at $\mathrm{pH} 3.5$.

The protein concentration was $1.5 \%$, dissolved in acetate buffer ( $\mathrm{pH} 3.5,50 \mathrm{~mm}$ ) containing $10 \mathrm{~mm}$ L-aspartate (A) or $0 \mathrm{~mm}$ (B). Pictures were taken at $72 \mathrm{~min}$ after achieving maximum speed $(51,200 \mathrm{rpm})$.

The upper schlieren pattern (A) was obtained by sedimenting L-asparaginase in $50 \mathrm{~mm}$ acetate buffer of $\mathrm{pH} 3.5$ containing L-aspartate; the lower pattern (B) was in the acetate buffer not containing the amino acid. Both were very similar. The sedimentation coefficients of the main peaks were $6.3 \mathrm{~s}$ (A) and $6.2 \mathrm{~s}$ (B) and those of the minor peaks were roughly 
estimated to be $2.5 \mathrm{~s}$ (A) and $2.6 \mathrm{~s}$ (B), respectively. The rapid sedimenting components in both systems probably represented the native enzyme protein, though the question remained on the difference between $s$ values of the native enzyme (about $7 \mathrm{~s}$ ) and of the acid treated enzyme (6.2s). The slow sedimenting components appeared to correspond to the dissociated form. There was no distinguishable difference in the ratios of the area of the main component to that of the minor component between the two systems.

Then, the reversibility of the dissociated form to the native one was examined. $\mathbf{L}$ Asparaginase was incubated at $\mathrm{pH} 3.5$ for $60 \mathrm{~min}$ at $47^{\circ} \mathrm{C}$ in the presence or absence of L-aspartate. Then, the enzyme solutions were dialyzed against $50 \mathrm{~mm}$ phosphate buffer $\mathrm{pH}$ 7.8 at $5^{\circ} \mathrm{C}$ over night. The enzyme treated without L-aspartate was irreversibly precipitated during dialysis. On the other hand, the enzyme solution treated in the presence of $\mathrm{L}$ aspartate remained clear after the dialysis. The sedimentation pattern of the dialysate was obviously homogenous and its $s$ value was calculated to be about $7.0 \mathrm{~s}$.

Therefore, the enzyme was dissociated partially into $2.5 \mathrm{~s}$ components when dissolved in the pH 3.5 buffer, whether the buffer contained L-aspartate or not. However, heating of the enzyme solution at $47^{\circ} \mathrm{C}$ caused its irreversible denaturation in the absence of $\mathrm{L}$ aspartate but not in its presence (Fig. 1). These findings mean that L-aspartate did not protect the enzyme from the dissociation at an acidic $\mathrm{pH}$ but protected it from irreversible inactivation.

\section{Effects of L-aspartate on activity and helix content}

The effects of L-aspartate on a tertiary structure of the enzyme were examined with ORD measurements. The results are summarized in Table IV. The helix content $(\%)$ as a criterion of the state of the enzyme structure was estimated from the rotatory dispersion constant $\lambda_{c}$ according to the Yang's equation. ${ }^{9)}$ The helix content of L-asparaginase was $31.4 \%$ at $\mathrm{pH} 7.9$ and it decreased to $18.2 \%$ at $\mathrm{pH} 2.8$, where the activity dropped to $45.9 \%$ of the activity at $\mathrm{pH} 7.9$. However, if $\mathrm{L}$-aspartate was added to the enzyme at $\mathrm{pH}$ 3.4 , it showed $80 \%$ of the activity at $\mathrm{pH} 7.9$. The addition of L-glutamate increased the activity only by $54 \%$.

On the other hand, the addition of L-glutamate or L-aspartate resulted in the decrease of the helix content at $\mathrm{pH} 7.9$ as compared with the enzyme solution without amino acid. The degree of the decrease in helix content did not differ each other. Moreover, in both enzyme solutions containing amino acids, lowering $\mathrm{pH}$ to $3.5 \mathrm{did}$ not cause further decreases in the helix contents, which had already become about $20 \sim 24 \%$ at $\mathrm{pH} 7.9$. Therefore, L-glutamate has the same effects on the changes in ORD spectrum as L-aspartate, while from the aspects of protective effect on

\section{Table IV. Effects of l-Aspartate on the Helix Content AND ACTIVITY OF L-ASPARAGINASE}

Enzyme solutions consisting of the L-asparaginase $2 \mathrm{mg} / \mathrm{ml}$, buffer (phosphate, or glycine $33 \mathrm{~mm}$ ) and the additives (L-aspartate or L-glutamate $10 \mathrm{~mm}$ ) were used for ORD measurements.

\begin{tabular}{|c|c|c|c|c|c|c|}
\hline $\mathrm{pH}$ & Additives & $\mathrm{mM}$ & $-[\alpha]_{\mathrm{D}}$ & $\begin{array}{c}\lambda_{c} \\
\mathrm{~m} \mu\end{array}$ & $\begin{array}{c}\text { Helix content } \\
\%\end{array}$ & $\begin{array}{c}\text { Activity } \\
\%\end{array}$ \\
\hline 7.9 & - & & 22.5 & 256.2 & 31.4 & 100.0 \\
\hline 7.9 & L-aspartate & 10 & 35 & 239.4 & 19.5 & 98.8 \\
\hline 7.9 & L-glutamate & 10 & 35 & 246.2 & 24.4 & 98.8 \\
\hline 2.8 & - & & 87 & 237.5 & 18.2 & 45.9 \\
\hline 3.4 & L-aspartate & 10 & 42.5 & 236.7 & 17.7 & 80.3 \\
\hline \multirow[t]{2}{*}{3.5} & L-glutamate & 10 & 40 & 241.7 & 22.2 & 53.8 \\
\hline & $0.1 \mathrm{~N} \mathrm{HCl}$ & & 97.0 & 214 & 1.4 & 0 \\
\hline
\end{tabular}


acid inactivation there was a remarkable difference between the two amino acids.

\section{L-Aspartate as an inhibitor of L-asparagine hydrolyzing activity}

L-Aspartate inhibited competitively the hydrolysis of L-glutamine and D-asparagine, and the $K i$ values were determined to be about $2.5 \times 10^{-3} \mathrm{M}$ against each substrate. The inhibition of L-asparagine hydrolysis by L-aspartate could be observed only when the concentration of L-asparagine was lowered to $2 \mathrm{~mm}$ which was still 100 times as high as its $\mathrm{Km}$ value and the concentration of L-aspartate was increased between 25 and 100 times as high as the $K i$ values of L-aspartate against Lglutamine and $\mathrm{D}$-asparagine hydrolyses (Table V).

TABLE V. INHIBITION OF L-AsParagine HYDROLYSIS BY L-ASPARTATE

The reaction mixtures consist of L-asparagine 2 and $20 \mathrm{~mm}, \mathrm{~L}$-aspartate $50 \sim 400 \mathrm{~mm}$ and the enzyme dissolved in phosphate buffer. Incubations were carried out at $37^{\circ} \mathrm{C}$ for $3 \mathrm{~min}$.

\begin{tabular}{ccc}
\hline Substrate & $\begin{array}{c}\text { L-Aspartate } \\
\text { added } \\
\mathrm{mM}\end{array}$ & $\begin{array}{c}\text { Activity } \\
\mathrm{mM}\end{array}$ \\
\hline 20 & 0 & 100.0 \\
20 & 50 & 92.6 \\
20 & 100 & 89.2 \\
2 & 0 & 100 \\
2 & 50 & 79.7 \\
2 & 100 & 59.4 \\
2 & 200 & 24.6 \\
2 & 400 & 0 \\
\hline
\end{tabular}

The type of inhibition by L-aspartate was not determined, but presumed to be competitive.

\section{DISCUSSION}

Protective action of L-aspartate on inactivation of L-asparaginase

The present studies have shown that Laspartate protected L-asparaginase from acid as well as from proteolytic inactivation and weakly from heat inactivation. On the other hand, L-asparagine showed a similar but less effective protection of the enzyme against acid inactivation. Consequently, the effects of L-asparagine $^{5 \text { ! }}$ in the protection against inactivation and in the profiles of the DEAE cellulose chromatography could be attributed to L-aspartate which was formed from the added L-asparagine during the treatment. These protective actions of L-aspartate were also observed with the enzymes from Serratia marcesens $^{12)}$ and Proteus vulgaris ${ }^{13}$ and appeared to be common to microbial L-asparaginases (EC 2).

Ryoyama $^{14}$ reported that certain guinea pigs possessed a thermostable asparaginase in their sera, whereas others possessed a thermolable form of the enzyme, and that both forms were stabilized against heat inactivation by $\mathrm{Na}^{+}$and $\mathrm{K}^{+}$On the other hand, none of metal ions and nucleotides tested possessed the protective action with the L-asparaginase from $E$. coli A-1-3.

On the mode of interaction between L-asparaginase and L-aspartate

In the presence of L-aspartate L-asparaginase was not absorbed on CM Sephadex column, but it was absorbed more tightly on DEAE cellulose column. This means that in the presence of L-aspartate, L-asparaginase behaved in the chromatographic characteristics as if it has got negative charge. The interaction between $\mathrm{L}$-aspartate and L-asparaginase seems to be highly specific and to relate closely to the protective action of L-aspartate. The binding force between the two was thought to be ionic from the above results. It appears, however, to be weak, because the protective action of L-aspartate was easily lost by a high concentration of sodium chloride $(0.5 \mathrm{M})$.

Subunit nature and the effect of L-aspartate on it

A variety of evidences ${ }^{15,16)}$ such as sedimentation studies, SDS gel electrophoresis, the stoichiometry of binding of DONV to the enzyme, ${ }^{17)}$ electron microscopy ${ }^{18}$ and Xray crystallography ${ }^{19}$ have supported the tetrameric structure of $E$. coli L-asparaginase. 
L-Asparaginase from $E$. coli $\mathrm{A}-1-3$ was also proved to consist of four subunits by means of SDS disc electrophoresis, ${ }^{20}$ the molecular weight of each being about 36,000 . There is indeed no direct evidence supporting that the four subunits are identical. However, only a single band was always observed for the subunits upon electrophoresis in $8 \mathrm{M}$ urea or $0.1 \%$ SDS, and in the sedimentation profile of the $L$-asparaginase dissolved in $8 \mathrm{M}$ urea or $5 \mathrm{M}$ guanidine hydrochloride. These results are consistent with an interpretation that the subunit may be identical.

Whether the separated subunits exhibit enzymatic activity or not has not been investigated. The remarkable ease with which the enzyme will reconstitute when agents such as urea are removed is one of the interesting properties of L-asparaginase. But, this property made it difficult to see whether the subunits have the enzymatic activity or not. However, as shown in the Results, the degree of the residual activity (about $60 \%$ ) in $3 \mathrm{M}$ urea corresponds well to the percentage of the areas of the undissociated form (58.4 $62.7 \%$ ) in $3 \mathrm{~m}$ urea, calculated from the sedimentation profiles. Thus, the subunits may not exhibit the enzymatic activity.

Kirschbaum et al. ${ }^{11}$ studied the effect of $\mathrm{pH}$ on the subunit structure of $E$. coli $\mathrm{B}$ asparaginase and observed two peaks at $\mathrm{pH} 3.3$, the sedimentation coefficients of which corresponded to 4.0 and $8.6 \mathrm{~s}$, respectively. A possibility that L-aspartate might inhibit the dissociation of the enzyme into subunits and that was the mechanism of its protective action was examined by studying the behaviors of the enzyme in the ultracentrifuge. The results obtained, however, denied this possibility.

\section{The effects of L-aspartate on the enzyme con- formation}

Proteases including $\alpha$-chymotrypsin, trypsin, subtilisin and thermolysin were able to attack and inactivate more or less the native Lasparaginase, and their inactivating action was equally suppressed with L-aspartate. Therefore, the proteolytic inactivation does not appear to depend on the cleavage of particular essential site(s) of the peptide chain, but on the degradation of the tertiary structure derived from the cleavage of many indefinite sites of the enzyme protein. If this is the case, the protective action of L-aspartate may be due to the induction of resistancy against proteases to the conformation of the active center and its surroundings, though many confirmative evidences will be required to establish this hypothesis.

In the case of acid inactivation, the situations appeared to differ from the proteolytic inactivation. The acid inactivation did not involve the cleavage of the peptide chain, but was accompanied by a partial dissociation. As mentioned above, L-aspartate exerted no influence on the dissociation and the association of the L-asparaginase. The protective action of $\mathrm{L}$-aspartate on acid inactivation may have stemmed from its action to suppress the change, for example unfolding, of the tertiary structure of the enzyme by high concentration of hydrogen ions.

Thus, the influence of L-aspartate on the tertiary structure was examined with ORD measurement. Unexpectedly, results obtained did not explain the protective action of $\mathrm{L}$ aspartate in terms of the preservation of the helical contents. Though L-glutamate caused a similar change in ORD spectrum, it did not exhibit a protective action on acid inactivation. Therefore, the remarkable decreases in the helical content by adding acidic amino acids seemed to have no relation to the induced resistancy against acid inactivation. It seems, therefore, better to think that the effective interaction between $\mathrm{L}$-asparaginase and Laspartate occurred on a limited part, for example, the active center on the enzyme.

L-Aspartate has been found to inhibit competitively the D-asparagine and L-glutamine hydrolysis reactions. It inhibited also to hydrolyze L-asparagine. These facts may suggest that L-aspartate occupy the active center and stabilize the enzyme against inactivation by acid, proteases or heat.

Jayaram demonstrated that L-aspartate acted 
as an allosteric inhibitor of the $\mathrm{pH} 9.6$ asparaginase from Mycobacterium. ${ }^{21}$ Though similar phenomena have not been observed with E.coli L-asparaginase, a possibility ${ }^{22}$ can not be ruled out that there might be other effector sites for L-aspartate than the active site for stabilizing the enzyme against inactivation. This is one of the problems to be solved.

Acknowledgement. The auther is very grateful to Dr. M. Tanaka for his helpful advices and also to Dr. K. Kimura, Dr. T. Oka and other collegues in our laboratory for their valuable discussions and assistances.

\section{REFERENCES}

1) J. D. Broome, Nature, 191, 1114 (1961).

2) H. F. Oettigen, L. J. Old, E. A. Boyse, H. A. Campbell, F. S. Philips, B. D. Clarkson, L. Tallal, R. D. Leeper, M. K. Schwartz and J. H. Kim, Cancer Res., 27, 2619 (1967).

3) J. M. Hill and J. Roberts, J. Am. Med. Assoc., 202, 882 (1967).

4) H. A. Whelan and J. C. Wriston Jr., Biochemistry 8, 2386 (1969).

5) N. Nakamura, Y. Morikawa, T. Fujio and $M$. Tanaka, Agr. Biol. Chem., 35, 219 (1971).

6) H. A. Campbell and L. T. Mashburn, Biochemistry, 8, 3768 (1969).

7) N. Nakamura, Y. Morikawa and M. Tanaka, Agr. Biol. Chem., 35, 743 (1971).
8) D. A. Cooney and R. D. Davis, Biochim. Biophys. Acta, 212, 134 (1970).

9) J. T. Yang, Tetrahedron, 13, 143 (1961).

10) M. Tanaka, T. Kagawa, T. Tatano, K. Mochizuki, N. Nakamura, K. Kohagura and J. M. Hill, Proc. 6th Inter. Congr. Chemotherapy, Tokyo, p. 260 (1969).

11) J. Kirschbaum, J. C. Wriston Jr. and O. T. Ratych, Biochim. Biophys, Acta, 194, 161 (1969).

12) T. Oka and M. Tanaka, personal communication.

13) R. Sano, K. Yamamoto, M. Nakamura, T. Tosa and I. Chibata, Abstracts of papers, The Annual Meeting of Agricultural Society of Japan, Tokyo, April, 1971, p. 252.

14) C. Ryoyama, Biochim. Biophys. Acta, 236, 8 (1971).

15) B. H. Frank, A. H. Pekar, A. J. Veros and P. P. K. Ho, J. Biol. Chem., 245, 3716 (1970).

16) H. Glossmann and W. Bode, Z. physiol. Chem., 352, 132 (1971).

17) R. C. Jackson and R. E. Handschumacher, Biochemistry, 9, 3585 (1970).

18) E. Irion and W.-H. Voigt, Z. physiol. Chem., 351, 1154 (1970).

19) O. Epp, W. Steigemann, H. Formamek, and R. Huber, Eur. J. Biochem., 20, 432 (1971).

20) N. Nakamura and M. Tanaka, Amino Acid, Nucleic Acid, 24, 96 (1971).

21) H. N. Jayaram, T. Ramakrisnan, M. Sirsi and C. S. Vaidyanathan, Indian J. Biochem., 7, 237 (1970).

22) M. Hirata, M. Tokushige, A. Inagami and $O$. Hayaishi, J. Biol. Chem., 240, 1711 (1965). 